\title{
The Lived Experience of Online Educators: Insights from Construction Management
}

\author{
Willy Sher ${ }^{1}$, Anthony Williams ${ }^{2}$ and Maria Northcote ${ }^{3}$ \\ ${ }^{1}$ Faculty of Engineering and Built Environment, University of Newcastle, Newcastle, Australia \\ ${ }^{2}$ Vice President (Academic and Research), Avondale College of Higher Education, Cooranbong, Australia \\ ${ }^{3}$ Faculty of Education, Business and Science, Avondale College of Higher Education, Cooranbong, Australia
}

\begin{abstract}
Academics in higher education institutions often experience the conflicting demands of teaching, research and administration. With the growth of online education these staff are frequently required to design, develop, teach, facilitate and, in some cases, administer online courses. Cumulatively these additional tasks challenge academics, not only in terms of the personal professional development but also in accommodating the range of tasks expected of them. This paper reports the findings of a study which investigated the lived experience of construction management academics teaching at universities in Australia. The study adopted a lived experience research approach that enabled the lives of construction management academics to be investigated through the collection of a mixture of qualitative and quantitative data. The study provides empirical evidence of a range of challenges facing those delivering online courses. Recommendations for online teachers and online course designers emerged from this study with application to both faculty-based and institution-wide practices. The findings are relevant to those in the higher education sector who are involved in online teaching, course design for online delivery and professional development related to online initiatives.
\end{abstract}

Keywords: Construction management, online education, professional learning

Paper Type: Research article

\section{Introduction}

Online education is seen as an increasingly important component of universities' long-term strategies (Allen and Seaman, 2013). The reasons for this growth include pressures from students, competitive imperatives, as well as economic pressures. This trend is world-wide and straddles most disciplines but it is acknowledged that some disciplines lend themselves to the online environment better than others. This paper explores the adoption of online education by the construction management (CM) discipline in Australia.

This paper provides an overview of the construction industry and the role of construction management degree programs within the context of the industry, followed by an analysis of some of the challenges facing course designers of such degree programs, especially in relation to online education. The methodology of the study is then described in relation to the demands of the industry and the higher education sector. The paper concludes by identifying the key findings of the study. These have informed a set of recommendations for practice and future research,

\footnotetext{
Copyright: Construction Economics and Building 2015. (C) 2015 Willy Sher, Anthony Williams and Maria Northcote. This is an Open Access article distributed under the terms of the Creative Commons Attribution 4.0 Unported (CC BY 4.0) License

(https://creativecommons.org/licenses/by/4.0/), allowing third parties to copy and redistribute the material in any medium or format and to remix, transform, and build upon the material for any purpose, even commercially, provided the original work is properly cited and states its license.
}

Citation: Sher, W., Williams, A. and Northcote, M., 2015. The lived experience of online education: insights from construction management, Construction Economics and Building, 15(2), 49-62. DOI: http://dx.doi.org/10.5130/AJCEB.v15i2.4398 
including issues associated with curriculum development, workload, professional development and the management of diverse student cohorts.

\section{Context}

The construction industry is a powerful driver of most countries' economies. Although Global Construction Perspectives and Oxford Economics (GCPOE) show that immediate prospects for continued growth in the sector appear bleak in some countries, the long-term outlook is positive (GCPOE, 2013). Over 60\% of global construction activity is forecast to occur in emerging markets by 2025 (up from 35\% in 2005) with Asia the fastest growing region, despite a slowdown in growth in China.

Closer to home, Australia's leading construction companies, the Australian Industry Group, (AIG, 2013) predicted a marked slowdown in the growth of non-residential construction work for 2013 and 2014 but these forecasts appear pessimistic in light of recent optimism noted by Heaton (2014). He records a surge in confidence across the residential, commercial and civil construction sectors in Australia.

Notwithstanding these forecasts, construction activity in Australia is beset by persistent difficulties in sourcing labour. The construction industry has suffered from a poor supply of construction professionals for some years (Clarius Group, 2012). The Department of Immigration and Border Protection (2013a, 2013b) has identified a national shortage of several categories of Construction Management (CM) professionals, including construction project managers, quantity surveyors, building associates, building inspectors and construction estimators. A range of construction professionals is needed both globally and in Australia, and graduate construction managers are well placed to fill these positions. In addition, tradespeople wishing to progress their careers are attracted to CM degree programs, especially when they are able to study online.

\section{Construction Management Degree Programs}

The construction workforce in Australia is characterised by low levels of formal qualifications (Figure 1). It is noteworthy how few university graduates there are (7.6\%). To satisfy this need, universities offering CM undergraduate degrees have increased their enrolments in recent years (Williams, Sher and Simmons, 2010). In their report on CM education Williams Sher and Simmons (2010) identified 12 CM degrees being offered in Australia and three additional programs (at the University of Canberra, the Open University and Holmesglen TAFE) have come on stream since then.

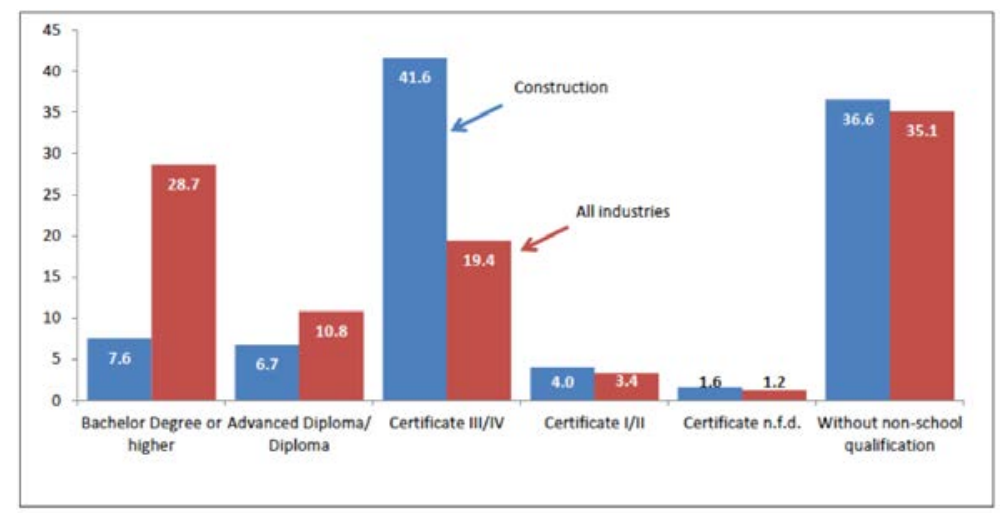

Figure 1: Education profile of the construction workforce in Australia (ABS (2012) Education and Work, Australia, May 2012. Cat. No. 6227.0 cited in NSW Department of Education and Communities, April 2013, p.16). 


\section{Construction Management Students}

CM students are predominantly drawn from two discrete streams: school leavers and students aged 21 years and older. Understandably they have significantly differing experiences and expectations. Recent analysis of Department of Education Employment and Workplace Relations data (Sher, 2012) indicates that CM students are typically older than their counterparts in other disciplines, with the most noticeable gap (approximately 7\%) being in the age group 25 to 29 years old. Many older students are already in the construction workforce and embark on university education to enhance their career prospects. Combining work and study is understandably difficult and these students feel apprehensive because many have not studied for some time. They are likely to hold responsible positions at work, and need to earn money to support themselves and, in many cases, their dependants. They have social and other commitments, and find managing their time a significant challenge. It is therefore understandable that many of them seek to continue working whilst they study. Consequently, flexible course delivery options are required to meet their needs.

Construction education has a long history of on-campus evening classes (Australian Technology Network, 2004; Lenard, 2008) and this model is still utilised by some universities. However, online learning provides students with further alternatives with some universities offering undergraduate CM programs in blended or online modes. For this paper, blended learning is defined as a combination of on-campus and online learning. It encompasses a continuum of face-to-face delivery through to full online learning. The online mode of course delivery is fast becoming the preferred option for students.

CM students are not alone in preferring online and flexibly delivered universities courses. This phenomenon represents a worldwide trend and aligns with the rapid and widespread use of learning and teaching technologies (Hacifazlioglu, Sacli and Yengin, 2007). According to Johnson et al., (2013) these demands are motivated by the flexibility such course delivery methods offer. This trend has created expectations that have fuelled the demand for online learning (Allen and Seaman, 2007; Koch and Fusco, 2008; Meanset al., 2010). Students' expectations for easy course access present yet another demand on academics who are continually responding to the "multiple changes imposed by forces from within and outside universities" (Devlin and Samarawickrema, 2010, p.111). These demands, in turn, require the modification of learning and teaching contexts.

\section{Problems Developing Curricula}

The CM curricula offered by universities in Australia reflect nuanced approaches to preparing construction professionals for their workplaces. They need to respond to legislative requirements including the Australian Qualifications Framework (Department of Innovation, Science and Research, 2011) and discipline threshold learning outcomes (Newton, 2011), university requirements (including each university's graduate attributes), as well as the requirements of the multiple professional institutions that accredit these degrees (noted above). In addition to formal curricula, academics need to be aware of and incorporate informal and hidden curricula. Hafferty (1998, p.404) defines these as:

... an unscripted, predominantly ad hoc, and highly interpersonal form of teaching and learning that takes place among and between faculty and students (the informal curriculum); and a set of influences that function at the level of organisational structure and culture (the bidden curriculum).

Additionally, curricula need to accommodate tacit requirements including the values and expectations that students acquire through their education (Barrow and McKimm, 2009).

While early versions of online courses have frequently been referred to as "shovelware", 
indicating the delivery of existing distance learning hardcopy materials in an online mode (Sparrow, Herrington, and Herrington, 2000), more recent developments include the use of interactive activities as well as opportunities for reflection and collaborative tasks to engage students in meaningful learning experiences (Hubball, Collins, and Pratt, 2005; McInnerney and Roberts, 2004; Palmer and Holt, 2009; Warwick et al., 2010). Online curricula attract a range of additional challenges that developers need to be cognisant of and respond to, especially in relation to the diverse nature of the students who enrol in such courses. Students enrolling in flexibly delivered online CM courses are often more IT savvy than their lecturers, being referred to by Prensky (2001) as "digital natives" who are adept at speaking the language of the internet. In fact, most students expect some form of online delivery and use of information and communication technologies (ICTs) to be integrated into their university studying experiences.

Despite changing students' demands and expectations, some academics remain hesitant to engage with online course design. Some have attempted to transform their face-to-face teaching practices into online teaching and learning activities (Birch and Burnett, 2009). This transformation of on-campus courses to flexibly-delivered online contexts present challenges to academics and their institutions, especially in relation to the increasingly complex skills required to design and deliver online courses. Tailored and varied types of professional development activities are required to support staff to develop appropriate online course design and facilitation skills (Doering et al., 2009; Ellis and Phelps, 2000; Rienties, Brouwer, and LygoBaker, 2013; Wall and Ahmed, 2007).

Student learning preferences also pose challenges for developers of online courses. Whilst some students may feel isolated and wish to actively engage with their peers and lecturers, others prefer to work in isolation and at their own pace. The difference in age and experience between students further compounds these challenges. Group work activities ostensibly provide attractive opportunities for younger students to benefit from the worldviews and experience of older students. However, school leavers are sometimes intimidated by their mature age counterparts, some of whom rely on their past experiences and avoid engaging with theories and solutions with which they are unfamiliar (Sher and Walker, 2013). A further dimension is that of the time-poor nature of older students' working lives. Their commitments often take precedence over their studies. The net result is that group work is difficult to facilitate despite the attractive learning opportunities it presents.

\section{Maintaining and Renewing Curricula}

Maintaining the integrity of a curriculum over time is difficult and those seeking guidance on curriculum renewal find:

... limited theoretical and empirical literature addressing whole of program curriculum development and renewal generally... Specifically, the theoretical underpinnings that guide such endeavours, the identification of what works, the engagement of key stakeholders (beyond faculty/staff), and evaluation of processes and outcomes are poorly understood. (Rodger, 2011, p.10)

Some of the challenges of maintaining and renewing CM curricula include:

- Maintaining currency of content. Topics that received scant attention a decade ago are now viewed as mainstream. For example, ecological sustainable development has attracted considerable attention in recent years (Cotgrave and Alkhaddar, 2006; Desha, Hargroves, and Smith, 2009; Hales and Holdsworth, 2006; Sherren et al., 2010), as has building information modelling (BIM Education Co-op, 2011; MacDonald and Mills, 2010), new forms of procurement (Love, Skitmore, and Earl, 1998; Rowlinson and McDermott, 1999; Walker and Rowlinson, 2008) and new construction technologies such as prefabrication and modular construction (Blismas et al., 2005; Gibb, 1999). In 
addition, existing courses need to acknowledge and respond to current priorities and developments. For example, building services have become increasingly sophisticated and complicated. Furthermore, the distinctions between some types of buildings have changed. Buildings that were considered high-rise, a decade ago, are now considered to be of a modest elevation, and revisions (and additions) to curriculum are required to address the challenges associated with working in these conditions.

- Maintaining the industry currency of academics. As universities develop their research profiles, the academics experience tensions between their university's requirement for them to have research-focused higher degrees, and the accrediting professional institutions who expect staff to have relevant and current work experience.

- Maintaining the integrity of curricula. With a changing staff profile, retirements and new appointments, it is important that curriculum documentation is sound and detailed. Care needs to be taken to ensure that the original aims and objectives of a curriculum are maintained. Small changes to course content accumulate over time and may dilute the manner in which topics in one course relate to those dealt with in other courses, potentially creating gaps in the curriculum and compromising its integrity.

- Developing online teaching and learning skills. Increasingly, it is expected that staff incorporate innovative uses of technology into their courses to meet students' need for flexibility. Academics responsible for developing and maintaining curricula, need to balance the demands of meeting university and program attributes, with the need to encourage staff to develop and introduce innovations in their courses. The ways in which universities manage these sometimes-conflicting requirements are in a state of flux. Boud and Brew (2013) suggest that academics' learning requirements need to be increasingly located in the practice of professionals. They recommend one or more of three approaches. Firstly, to embed students' learning in real world problems through curricula that include Problem Based Learning approaches that employ real industry projects. Secondly, staff should individually, or as teams, engage with industry by involving themselves in projects. Thirdly, staff should reflect on their teaching and learning approaches and research current practices (Boud and Brew, 2013). These recommendations take into account the increasing uptake of online education by students, institutions and teaching staff.

\section{Requirements for Online Delivery}

In light of the challenges facing the $\mathrm{CM}$ discipline, its associated accrediting professional institutions and the universities from which many $\mathrm{CM}$ employees graduate, greater flexibility is required in the mode of delivery of $\mathrm{CM}$ courses. Because of their diverse backgrounds, online delivery is becoming increasingly attractive to $\mathrm{CM}$ students. These students are generally older than mainstream students. Consequently, many work to support themselves and their families whilst they study. Many are highly computer literate (though anecdotal evidence indicates that some CM students might not be as computer savvy as mainstream university students). Further complicating these requirements is the desire of students to graduate as soon as they can (prompting at least one university to deliver an accelerated three year degree program in trimesters over two years). These factors bring online delivery into sharp focus as an approach that meets the requirements of contemporary CM students.

Online delivery of CM courses in universities offer students a high level of flexibility (Johnson et al., 2013), opportunities for interaction and collaboration with other colleagues (Garrison and Cleveland-Innes, 2005; Gunawardena, 1995; McInnerney and Roberts, 2004; Picciano, 2002) and a setting in which their professional and identities can develop (Koole, 2010). By tailoring courses to suit the needs of their students, university courses designed for online learning environments have the potential to meet many of the needs of diverse student bodies. 


\section{The Research Design}

This paper is based on an investigation (Williams, Sher and Simmons, 2010) that was designed to identify and understand the factors that impact on CM academics' day-to-day and longer-term activities. Substantial data were collected but were not reported on in the aforementioned publication. This paper explores these data through the lens of the lived experiences of CM academics. We were able to document the expectations the construction industry has of undergraduate management education, the curricula taught, the approaches used to teach and assess students, the characteristics of $\mathrm{CM}$ cohorts, and how $\mathrm{CM}$ academics are themselves managed and supported.

A mixed-method research methodology (MMR) was adopted as described below. Qualitative data from an online survey were used to confirm some of the findings of the interviews and focus groups. MMR was used to triangulate as well as to complement the qualitative results of the online survey with those of the interviews and focus groups.

An online survey was conducted to identify issues affecting the provision of education to this discipline. All full time CM academics in Australia were invited to complete the survey, and a response rate of $54 \%$ was achieved. Issues identified in the survey responses informed the ensuing investigations. The survey was comprised of the following four sections: (1) demographic details; (2) curriculum issues; (3) learning and teaching, and generating academic knowledge; and (4) academics conditions. One hundred and thirty seven options were provided to respondents in a range of formats including Likert-scale options, ranking of options, choice from a range of options, as well as free format responses.

Following an analysis of the survey data, focus groups and interviews were conducted with the academics and heads of school of 11 of the 12 universities delivering CM programs at the time (Williams, Sher and Simmons, 2010). The audio recordings of the focus group discussions and the interviews were transcribed and analysed using NVivo (QSR, 2008). The findings were distilled into five domains that impacted on the lived experiences of $\mathrm{CM}$ academics (Figure 2).

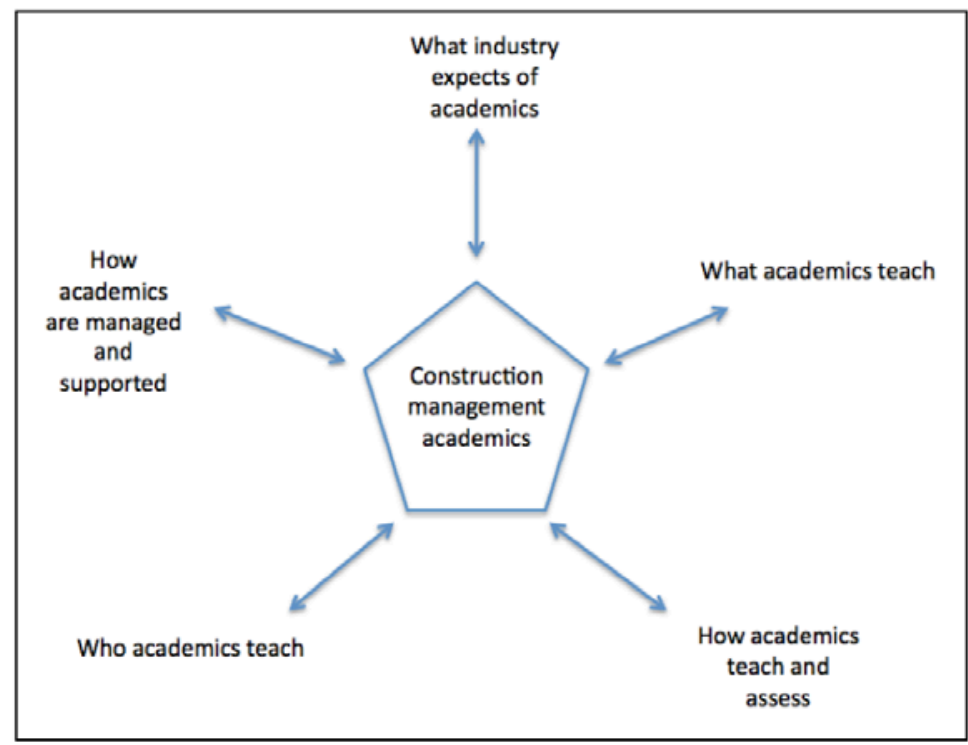

Figure 2: Domains that impact on the lived experiences of CM academics

This study is founded on the observations of a cohort of CM academics at a specific stage of their careers. Furthermore, it is based on the resources they had available at the time, the environment in which they found themselves and the students enrolled in their courses. It is likely and expected that these will all change with time. This does not undermine this study. The contribution of this study is that it provides a snapshot at a point in time against which future developments may be measured. 


\section{Key Findings}

The findings presented in this study (Sher, 2012) reflect concerns similar to those expressed in current, global research (Houston, Meyer, and Paewai, 2006; Larkins, 2013) about workloads of academic teaching staff across a range of disciplines. Issues such as administration workload, electronic communication, student demands, research pressures and accreditation requirements are familiar to academics in many other disciplines. Findings of specific relevance to the CM discipline are discussed below.

\section{Lack of online course development and delivery skills}

Participants indicated that they were largely self-taught with respect to online teaching and learning. Very few had availed themselves of the opportunities provided by their universities to develop their understanding of the possibilities, affordances and constraints of online learning and teaching. Some spoke of the difficulties they had experienced in delivering courses online, and it became apparent that they were attempting to use inappropriate (face-to-face) approaches in an online environment. This aligns with the experiences of academics in other disciplines who attempted to deliver online by transforming hardcopy distance learning materials into their digital equivalents; a practice known as "shovelware", described above. The folly of such endeavours is well documented (Birch and Burnett, 2009; Sparrow, Herrington and Herrington, 2000). It is therefore unsurprising that some participants expressed reservations about delivering courses online.

\section{Reluctance to engage with online teaching and learning}

Some participants expressed their personal reluctance to engage with online teaching and learning approaches. Reasons for this were inferred by the ranking of their teaching requirements in the online survey. Online teaching and learning resources was ranked fourth out of 12 needs and professional development as fifth. It is thus likely that their hesitancy to embrace online approaches was in part be due to lack of resources and skills.

In contrast, some noted that their institution/discipline had built its reputation on providing a strong face-to-face experience for their students, seeing this as distinguishing them from other universities and remain unconvinced as to adopting online delivery. Of note since these views were expressed, is that at least one university concerned now provides Massive Open Online Courses (MOOCs), indicating a commitment to online course delivery.

\section{Attendance}

A primary concern expressed by participants was that online delivery would reduce the number of students attending face-to-face lectures. Online delivery was observed by participants as popular with on-campus students. Academics viewed poor class attendance as problematic because it detracted from an engaging experience for staff and students as illustrated in this quote from a participant staff member:

As we make more and more use of the Blackboard [the institution's online Learning Management System], and we give recordings of lectures and things, students feel that they can catch up and they don't come to class. That means then it's kind of awkward talking to hardly anybody. Suddenly your lecture performance takes a dive and I suppose everybody loses out then in a way. 


\section{Discussion}

The reluctance of some to use online technologies could be addressed through provision of professional development activities. However, CM academics appeared to have little time or energy for introspection and contemplation of future teaching and learning enhancement. The manner in which such opportunities are communicated to academics is important, this study showing that few academics availed themselves of development activities in online teaching and learning. The reluctance of CM academics to engage with online delivery may be generational and, therefore, may self-correct with time as they become more experienced and confident in developing skills to construct and facilitate online courses.

Many of the student-participants in this study were more positive about the use of online technologies in their courses than their lecturers, though some had concerns about the use of digital technology, especially the perceived lack of immediacy felt in online activities. This problem can sometimes be solved through application of synchronous teaching and learning tools such as video or audio conferencing sessions (e.g., Blackboard's Collaborate or Adobe Connect) but the lack of an online presence is recognised by both online teachers and online students as an area of concern (Anderson et al., 2001; Jones, Naugle, and Kolloff, 2008; Lehman and Conceição, 2010; Northcote, 2010; Picciano, 2002; Richardson and Swan, 2003; Warwick et al., 2010). This aspect presents some challenges for online course designers and, especially in the context of this study, CM students who, due to their diversity, frequently require flexible enrolment in their courses.

How teachers and students maintain their online presence is closely related to the extent to which they interact in their online courses. However, as Garrison and Cleveland-Innes (2005, p. 133) remind us, "Interaction is not enough" when "facilitating cognitive presence in online learning". They found that structure, leadership and course design have a profound impact on the level of presence achieved in an online learning context. This study has highlighted that the high demand for flexible, online delivery course options that recognise and accommodate the current levels of instructors' skills and students' preference for teacher presence and social interactions.

Our study has provided a detailed insight into the pressures under which university academics operate in CM courses, and especially acknowledges and explores the complex mix between the demands made on academics. While they are expected to be industry-current, academically rigorous and research active, they are also expected to be pedagogically sound educators, dynamic teachers, innovative curriculum designers and, in many cases, ever-present advisors for students. This finding also has implications for $\mathrm{CM}$ academics as they delve further into online learning contexts but the situation is not unique to $\mathrm{CM}$ academics. Academics in many disciplines are currently grappling with similar pressures and demands (Allen and Seaman, 2013; Palloff and Pratt, 2002; Shea, 2007).

In summary, it is apparent that there are tensions between the expectations of some employers for job-ready graduates, and the aspirations of some academics who wish to prepare graduates for the longer-term challenges they will encounter in their profession. The expectation for students to be job-ready when they graduate is not unique to the construction industry. Similar expectations are apparent in fields as diverse as tourism (Wang, Ayres, and Huyton, 2009), software development (Begel and Simon, 2008) and nursing (Romyn et al., 2009).

Some universities have embraced opportunities to reach out to wider audiences, through increased offerings of online and blended courses, whilst others have retained their traditional focus of on-campus delivery. As Head of School at one university said "(This) university is deliberately a face-to-face university. We make a deliberate decision to not go distance." 
Similarly, another Head of School stated that "(This) university will never be an online institution. You'll never be able to go through and do a degree here, an undergraduate or a masters, online. It will not happen." This reticence to extend courses into the online realm is also present in other academic disciplines and has been found to relate to a teacher's identity and selfefficacy in online education (Abbitt, 2011; Gosselin, 2009; Koole, 2010; Shepherd, Alpert, and Koeller, 2007).

\section{Recommendations for Practice and Future Research}

The implications from the results of this study reach into the areas of curriculum design, including online presence, workload associated with online delivery, the professional development of CM academics and the management of diverse cohorts of students.

\section{Curriculum development}

It was found that there was widespread awareness of the potential benefits offered by curricula that were prepared and presented online, from both students and teachers. Students mentioned that they valued having teaching and learning resources available online. These were seen to supplement their other traditional materials and approaches. Students saw digital media as an efficient way of accessing teaching and learning materials.

Despite being able to access materials before and after lectures, being able to access recordings at any time, being able to selectively review sections of such recordings, and being able to avoid travelling to and from university, participants identified some shortcomings of digital teaching and learning. These were typically focused on the lack of teacher and student presence that was offered by online contexts. Some lecturers noted that online delivery was ineffective in communicating subtle visual cues:

This facial and body language, it can't be described in word or in sound. Secondly, the communication with the lecturer is immediate. If I see you understand, if you missed something, or you don't understand the concept, I can immediately see, detect from your facial express(ions), right? And then I can adjust my delivery and emphasise a certain concept, give more illustrations. That can't be done (online).

The perceived lack of humanness in online learning environments indicates that professional development opportunities for $\mathrm{CM}$ academics require instruction on how to create and maintain a healthy online presence. Such a presence facilitates online interactions, engagement and, ultimately, the quality of student learning. Along with the benefits of accessing flexibly delivered courses, the responsibilities of students in such a mode also need to be defined and communicated so as to share a common understanding of online communication.

\section{Workload}

There was general agreement amongst academics in this study that they were overworked, especially amongst those who were attempting to complete a $\mathrm{PhD}$ while working full time. Our findings provide strong evidence that the lived experience of a typical CM academic is one that reflects a high workload, involving engagement in research, teaching and administration. Many felt pressured to maintain and update their industry knowledge, and to engage with online course delivery (new to many). They thus face the multiple pressures of needing to be effective teachers, administrators and productive researchers (Reeves, McKenney, and Herrington, 2011).

The increased workload experienced by CM academics may be attributable to increased demand for online courses from students and university administrators. The following observation of a Head of School highlights concerns about teaching online, and was echoed by other participants: 
We spend an awful lot more time online and preparing materials that are suitable for online delivery. That used not to be a consideration at all... the kinds of things that don't seem to be a problem to start off with because you're delivering them first and foremost to on-campus students, can become a horrendous problem when you start using the same materials with distance-learning students.

In practical terms, workload issues for CM staff, especially issues related to online course design and online course facilitation, appear to be more problematic when little is done to develop new skills and approaches. It would appear important to not only value the role of focused and specific professional development to assist in developing online teaching skills, but also recognise the time and resources required to respond to the needs of the diverse range of their students.

Burgeoning workload has implications for individual academics as well as for their managers and leaders. On an individual basis, academics need to be strategic about the activities they devote their time to. In addition, those responsible for managing these disciplines need to seek out ways of containing growth in administrative tasks, especially when university policies and processes are becoming more complex and diverse.

\section{Professional development}

In many of the cases analysed in this study, $\mathrm{CM}$ academics appeared to use online teaching and learning in an arbitrary manner and their skills in engaging students online appeared to be ad hoc. This indicates that CM academics would benefit from developing skills in online delivery. This is not to say that the universities represented in this study did not offer such professional development opportunities. Rather, it indicates that staff, for one reason or another, did not engage with them. Ways need to be found to turn this situation around.

\section{Management of diverse student cohorts}

While blended course delivery appears to be a pragmatic solution to the changing demands currently being made on tertiary institutions, it presents a different set of challenges to those inherent in either distance or on-campus learning. For example, catering for diverse cohorts of students is challenging, as the following observation of one Head of School indicates.

It's a challenge because on-campus and distance-learning students have traditionally had quite different cultures. The distance-learners would have predominantly been industry practitioners and I guess they still are whereas the on-campus students are predominantly school leavers. To put it slightly differently, there are people on campus who come in knowing that they don't know much, whereas there are a lot of distance-learners who come into the program believing that they know everything. So when you bring those two groups together it can lead to a lot of friction.

Some students argued that online materials encouraged them to become complacent about their studies. Recent survey results from the USA (Allen and Seaman, 2014) reinforce the challenges of studying online. Respondents to this survey observed that students required more selfdiscipline to complete online courses than traditionally taught courses. However, online courses offer opportunities to students to manage their busy lives and conflicting demands on their time, and the participants in this study appreciated these opportunities. Consequently, lecturers and university administrators who make decisions about what courses to offer distance, on-campus and online students need to recognise that student cohorts are less homogenous than previously. This study has shown that combining students with diverse needs can have workload implications for lecturers and generate opportunities for conflict for students. 


\section{Conclusions}

The growth in online education generally and in the construction management discipline in Australia, specifically, formed the basis for this study. Together, the needs and activities of the $\mathrm{CM}$ industry and CM academics further informed the design of the methodology adopted. Previous research into e-learning in the CM context identified possibilities for online courses to meet many of the needs of diverse student cohorts while also attending to some of the key demands of professional and government bodies, accrediting institutions and industry groups.

This study has identified numerous pressures that impact on CM academics. These include the requirements of universities for academics to engage in research activities and to secure research funding, and to provide meaningful teaching and learning opportunities for their students. These academics also need to accommodate the diverse demographics of their students and harness new online approaches in their teaching. Academics are also expected to take on administrative duties and community engagement activities. Furthermore, industry expects that those teaching into these programs are familiar with current industry practices.

The CM discipline, in concert with other disciplines worldwide, is embracing online and blended delivery. Academics as well as students need to adapt and develop new approaches and skills if the potential for these technologies is to be harnessed effectively.

Collectively, these opportunities create pressures and tensions. Universities and industry sometimes have different expectations of academics. Many universities recognise research as their main activity, but industry views universities as educators of students. Academics and students do not always appreciate the challenges faced by each other. Finding ways to accommodate and ameliorate these tensions is a challenge for the future.

The findings presented in this paper may be of interest to academic teaching staff and administrators of CM courses within universities, accrediting institutions, government bodies and industry-based individuals and groups.

\section{Acknowledgements}

We wish to acknowledge support from the Australian Learning and Teaching Council (now the Office for Learning and Teaching) who funded the discipline-based initiative on which this paper is based.

\section{References}

Abbitt, J.T., 2011. An Investigation of the Relationship between Self-Efficacy Beliefs about Technology Integration and Technological Pedagogical Content Knowledge (TPACK) among Preservice Teachers. Journal of Digital Learning in Teacher Education, 27(4), pp.134-43. doi: http://dx.doi.org/10.1080/21532974.2011.10784670

Allen, I.E. And Seaman, J., 2007. Online Nation. Five Years of Growth in Online Learning. Needham, Mass.: Sloan Consortium.

Allen, I.E. And Seaman, J., 2013. Changing Course: Ten Years of Tracking Online Education in the United States. Babson Survey Research Group Report. Retrieved from: ERIC.

Allen, I. and Seaman, J., 2014. Grade Change - Tracking Online Education in the United States. Babson Survey Research Group and Quahog Research Group, LLC. Available at: http://www.onlinelearningsurvey.com/highered.html

Anderson, T., Liam, R., Garrison, D.R. and Archer, W., 2001. Assessing teacher presence in a computer conferencing context. Journal of Asynchronous Learning Networks, 5, pp.1-17.

Australian Technology Network, 2004. History of the Australian Technology Network (ATN) of Universities [Online] Australian Technology Network. Available at: http://www.atn.edu.au/about/history.htm [Accessed 5 November 2008].

Barrow, M and McKimm, J. Curriculum and course design, The British Journal of Hospital Medicine, Vol 70 (12), 592-596. 2009

Begel, A. and Simon, B., 2008. Struggles of new college graduates in their first software development job. ACM SIGCSE Bulletin,SIGCSE 08, 40(1), pp.226-30. 
Bim Education Co-Op., 2011. BIM Education University [Online] Available at: http://bimdelivery.com/ [Accessed 2 January 2011].

Birch, D. and Burnett, B., 2009. Bringing academics on board: Encouraging institution-wide diffusion of e-learning environments. Australasian Journal of Educational Technology, 25(1), pp.117-34.

Blismas, N.G., Pendlebury, M., Gibb, A. and Pasquire, C., 2005. Constraints to the Use of Off-site Production on Construction Projects. Architectural engineering and design management, 1(3), pp.153-162.

Boud, D. and Brew, A., 2013. Reconceptualising academic work as, professional practice: implications for academic development. International Journal for Academic Development, 18(3), pp.208-21. doi: http://dx.doi.org/10.1080/1360144X.2012.671771

Clarius Group, 2012. Clarius Skills Index [Online] Sydney: Clarius Group Ltd. Available at: http://www.clarius.com.au/news_centre/clarius_skills_index.aspx [Accessed 22 April 2012].

Cooperative Network of Building Researchers Network, 2008ISI Listing of CM Journals. [online Electronic discussion] CNBR[Accessed 7 to 25 November2008]. Available at: http://groups.yahoo.com/group/cnbr$1 /$ join

Cotgrave, A. and Alkhaddar, R., 2006. Greening the Curricula within Construction Programmes. Journal for Education in the Built Environment, 1(1), pp.3-29. doi: http://dx.doi.org/10.11120/jebe.2006.01010003

Department of Immigration and Border Protection, 2013a. Consolidated Sponsored Occupation List (CSOL) [Online] Available at: http://www.immi.gov.au/skilled/sol/ [Accessed 26 September 2013].

Department of Immigration and Border Protection, 2013b. Skilled Occupation List (SOL) [Online] Available at: http://www.immi.gov.au/skilled/sol/ [Accessed 26 September 2013].

Department of Innovation, ndustryScience and Research, 2011. Defining Quality for Research Training in Australia: a Consultation Paper. Australian Government. [online] Available at: http://www.hestandards.gov.au/sites/default/files/DefiningQualityforResearchTraininginAustralia_0.pdf

Desha, C.J., Hargroves, K.C. and Smith, M.H., 2009. Addressing the time lag dilemma in curriculum renewal towards engineering education for sustainable development. International Journal of Sustainability in Higher Education, 10(2), pp.184-99. doi: http://dx.doi.org/10.1108/14676370910949356

Devlin, M. and Samarawickrema, G., 2010. The criteria of effective teaching in a changing higher education context. Higher Education Research and Development, 29(2), pp.111-24. doi: http://dx.doi.org/10.1080/07294360903244398

Doering, A., Veletsianos, G., Scharber, C. and Miller, C., 2009. Using the technological, pedagogical, and content knowledge framework to design online learning environments and professional development. Journal of Educational Computing Research, 41(3), pp.319-46. doi: http://dx.doi.org/10.2190/EC.41.3.d

Ellis, A. and Phelps, R., 2000. Staff development for online delivery: A collaborative, team based action learning model. Australian Journal of Educational Technology, 16, pp.26-44.Garrison, D.R. and Cleveland-Innes, M., 2005. Facilitating cognitive presence in online learning: Interaction is not enough. The American Journal of Distance Education, 19(3), pp133-48.

Gibb, A.G.F., 1999. Off-site fabrication: prefabrication, pre-assembly and modularisation. New York, NY:John Wiley and Sons.

Global Construction Perspectives and Oxford Economics, 2013. Global Construction 2025. A global forecast for the construction industry to 2025. London, UK: Global Construction Perspectives and Oxford Economics.

Gosselin, K.P., 2009. Development and Psychometric Exploration of the Online Teaching Self-efficacy Inventory. PhD. Texas Tech University.

Gunawardena, C.N., 1995. Social presence theory and implications for interaction and collaborative learning in computer conferences. International journal of educational telecommunications, 1(2), pp.147-66.

Hacifazlioglu, O., Sacli, O.A. and Yengin, I., 2007. Lecturers' Attitudes Towards the use of Technology: Alternative Strategies for Faculty Administrators. In: $7^{\text {th }}$ International Educational Technology (IETC) Conference. Nicosia, Turkish Republic of Northern Cyprus. May 3-5, 2007.

Hafferty, F.W., 1998. Beyond curriculum reform: Confronting medicine’s hidden curriculum. Academic Medicine, 73(4), pp.403-07. doi: http://dx.doi.org/10.1097/00001888-199804000-00013

Hales, C.S. and Holdsworth, S.E., 2006. Curriculum change for sustainability. Built environment education annual conference (BEECON). 2006. Bonnington Hotel, London. 12-13 September. CEBE.

Heaton, A., 2014. Builder Confidence Hits Six Year Highs. Sourceable Industry News and Analysis [Online]. Available at: http://sourceable.net/builder-confidence-hits-six-year-highs/ [Accessed 28 April 2014].

Houston, D., Meyer, L.H. and Paewai, S., 2006. Academic Staff Workloads and Job Satisfaction: Expectations and Values in Academe. Journal of Higher Education Policy and Management, 28(1), pp.17-30. doi: http://dx.doi.org/10.1080/13600800500283734

Hubball, H., Collins, J. and Pratt, D., 2005. Enhancing reflective teaching practices: Implications for faculty development programs. Canadian Journal of Higher Education, 35(3), pp.57-81.

Johnson, L., Adams, S., Cummins, M., Estrada, V., Freeman, A. and Ludgate, H., 2013. The NMC Horizon Report: 2013 Higher Education Edition. Austin, Texas.

Jones, P., Naugle, K. and Kolloff, M., 2008. Teacher presence: Using introductory videos in online and hybrid courses. Learning Solutions Magazine. 
Koch, M. and Fusco, J., 2008. Designing for growth: Enabling communities of practice to develop and extend their work online. In: Kimble, C. and Hildreth, P. (eds.) Communities of practice: Creating learning environments for educators. North Carolina: Information Age Publishing.

Koole, M., 2010. The web of identity: Selfhood and belonging in online learning networks. In: 7th International Conference on Networked Learning. Aalborg, Denmark, May 2010.

Larkins, F.P., 2013. Academic Staffing Trends: At what cost to teaching and learning excellence? LH Martin Institute Insights Blog, [blog] Available at: http://www.lhmartininstitute.edu.au/insights-blog/2011/10/65-academicstaffing-trends-at-what-cost-to-teaching-and-learning-excellence [Accessed 20 April 2013].

Lehman, R.M. and Conceição, S.C., 2010. Creating a sense of presence in online teaching: How to" be there" for distance learners. San Fransiscao CA: John Wiley and Sons.

Lenard, D., 2008. Education, Universities and Colleges. In: Main, T., (ed.) The History of Quantity Surveying in Australia. Canberra: The Australian Institute of Quantity Surveyors.

Love, P.E.D., Skitmore, M. and Earl, G., 1998. Selecting a suitable procurement method for a building project. Construction Management and Economics, 16(2), pp.221-33. doi: http://dx.doi.org/10.1080/014461998372501

Macdonald, J.A. and Mills, J.E. Can BIM be used to improve building design education? 35th AUBE A Conference, Melbourne 14 - 16 July 2010. The University of Melbourne.

McInnerney, J.M. and Roberts, T.S., 2004. Online learning: Social interaction and the creation of a sense of community. Educational Technology and Society, 7(3), pp.73-81.

Means, B., Toyama, Y., Murphy, R., Bakia, M. and Jones, K., 2010. Evaluation of evidence-based practices in online learning: A meta-analysis and review of online learning studies. Washington DC: US Department of Education.

Newton, S., 2011. Learning and Teaching Academic Standards Project - Building and Construction Learning and Teaching Academic Standards Statement. Australian Learning and Teaching CouncilStrawberry Hills, NSW: ALTC.

Northcote, M.T., 2010. Lighting up and transforming online courses: Letting the teacher's personality shine. In: Steel, C.H., Keppell, M.J., Gerbic, P. and Housego, S., (eds.) Curriculum, technology and transformation for an unknown future. Sydney, NSW: ASCILITE (Australasian Society for Computers in Learning in Tertiary Education).

NSW Department of Education and Communities, 2013. Smart and Skilled: Industry Profile Construction. Darlinghurst: NSW Government.

Palloff, R.M. and Pratt, K., 2002. Lessons from the cyberspace classroom: The realities of online teaching. San Francisco: Jossey Bass.

Palmer, S. and Holt, D., 2009. Staff and student perceptions of an online learning environment: Difference and development. Australasian Journal of Educational Technology, 25(3), pp.366-81.

Picciano, A.G., 2002. Beyond student perceptions: Issues of interaction, presence, and performance in an online course. Journal of Asynchronous Learning Networks, 6(1), pp.21-40.

Prensky, M., 2001. Digital natives, digital immigrants. On the Horizon, 9(5), pp.1-6. doi: http://dx.doi.org/10.1108/10748120110424816 and http://dx.doi.org/10.1108/10748120110424843

QSR International, 2008. NVivo 8 [Online] Available at: http://www.qsrinternational.com/products_nvivo.aspx [Accessed 20 Dec 2008].

Reeves, T.C., Mckenney, S. and Herrington, J., 2011. Publishing and perishing: The critical importance of educational design research. Australasian Journal of Educational Technology, 27(1), pp.55-65.

Richardson, J.C. and Swan, K., 2003. Examining social presence in online courses in relation to students' perceived learning and satisfaction. Journal of Asynchronous Learning Networks, 7(1), 68-88.

Rienties, B., Brouwer, N. and Lygo-Baker, S., 2013. The effects of online professional development on higher education teachers' beliefs and intentions toward learning facilitation and technology. Teaching and Teacher Education, 29, pp.122-31. doi: http://dx.doi.org/10.1016/j.tate.2012.09.002

Rodger, S., 2011. Building capacity among emerging occupational therapy academic leaders in curriculum renewal and evaluation at UQ and nationally (Final Report). Strawberry Hills, Australia: University of Queensland.

Romyn, D.M., Linton, N., Giblin, C., Hendrickson, B., Houger Limacher, L., Murray, C., Nordstrom, P., Thauberger, G., Vosburgh, D. and Vye-Rogers, L., 2009. Successful transition of the new graduate nurse. International Journal of Nursing Education Scholarship, 6(1). doi: http://dx.doi.org/10.2202/1548-923X.1802

Rowlinson, S. and McDermott, P., 1999. Procurement systems: A guide to best practice in construction. London: $\mathrm{E}$ and $\mathrm{FN}$ Spon.

Shea, P., 2007. Bridges and barriers to teaching online college courses: a study of experienced online faculty in thirty six colleges. Journal of Asynchronous Learning Networks, 11(2), pp.73-128.

Shepherd, C., Alpert, M. and Koeller, M., 2007. Increasing the Efficacy of Educators Teaching Online. International Journal of Social Sciences, 2(3), pp.172-78.

Sher, W., 2012. Tertiary construction management education: the lived experience of academic staff in Australia. $\mathrm{PhD}$. The University of Newcastle.

Sher, W. and Walker, K., 2013. Developing undergraduate construction management students' abilities to manage projects through a computer-based simulation. Business Education Innovation Journal, 5(2), pp.68-74.

Sherren, K., Robin, L., Kanowski, P. and Dovers, S., 2010. Escaping the disciplinary straitjacket: Curriculum design as university adaptation to sustainability. Journal of Global Responsibility, 1(2), pp.260-78. doi: http://dx.doi.org/10.1108/20412561011079399 
Sparrow, H., Herrington, J. and Herrington, A., 2000. 'Shovelware' as staff development: A useful introduction to moving online. In: Moving Online: A conference to explore the challenges for workplaces colleges and universities. Gold Coast, Qld, 18-19 August 2000, pp. 236-46.

The Australian Industry Group, 2013. Growth in major construction work to slow markedly. Construction Outlook [Online]. Available at:

http://www.aigroup.com.au/portal/binary/com.epicentric.contentmanagement.servlet.ContentDeliveryServlet /Live_Content/Economic Indicators/Construction Survey/2013/ACA outlook report May 2013 Final.pdf [Accessed 29 August 2013].

Walker, D. and Rowlinson, S., (eds.) 2008. Procurement systems - A cross disciplinary perspective. Abingdon: Taylor and Francis.

Wall, J. and Ahmed, V., 2007. Lessons learned from a case study in deploying blended learning continuing professional development. Engineering, Construction and Architectural Management, 15(2), pp.185-202. doi: http://dx.doi.org/10.1108/09699980810852691

Wang, J., Ayres, H. and Huyton, J., 2009. Job ready graduates: A tourism industry perspective. Journal of Hospitality and Tourism Management, 16(1), pp.62-72. doi: http://dx.doi.org/10.1375/jhtm.16.1.62

Warwick, P., Mercer, N., Kershner, R. and Staarman, J.K., 2010. In the mind and in the technology: The vicarious presence of the teacher in pupil's learning of science in collaborative group activity at the interactive whiteboard. Computers and Education, 55(1), pp.350-62. doi: http://dx.doi.org/10.1016/j.compedu.2010.02.001

Williams, A., Sher, W. and Simmons, C., 2010. Construction education in Australia: a review of learning and teaching challenges and opportunities, ALTC. 